\title{
Ben Tosland
}

Kent School of Architecture, University of Kent, Canterbury, United Kingdom

bt236@kent.ac.uk address: 6 Joseph Conrad Drive, Aldington, Ashford, Kent, TN25

7ET

Ben Tosland is a PhD Candidate in the Kent School of Architecture at the University of Kent. His research encompasses the region of the Persian Gulf and the reasons for geographical shifts of focus in its development - planning and architecture - throughout the twentieth-century. 


\section{Planning southern Iraq: Placing the progressive theories of Max Lock in Um Qasr, Margil and Basra in the context of Iraqi national development, 1954-6.}

Between 1954 and 1956, the architect, educator and planner, Max Lock (1909-1988), produced a trilogy of plans to modernise the historical city of Basra and create new areas at Margil and Um Qasr in the south of Iraq. The New Basrah Plan was heavily inspired by the works of Patrick Geddes and aligned with contemporaries such as Lewis Mumford, Lock's planning was progressive in scope and looked to differ from the planning of post-war principles in Britain through his notions of 'civic surgery'. Contrary to this, his plans for Um Qasr and Margil focussed on infrastructure and the creation of more industrial areas not prioritising people and place as highly as he did in the New Basrah Plan. Lock's 'Civic Surgery' offered an alternative to mainstream thought by attempting to create usable, humanistic spaces, which hampered by politics and legislation, resulted in the plan's shelving and were contradicted by his other works' philosophies. New retrospective analysis of his underappreciated career reveals the complexities of his planning which this article demonstrates through the 'failure' of the New Basrah Plan and his plans at Um Qasr and Margil.

Keywords: Planning, architecture, modernisation, modernism, Max Lock, Iraq 


\section{Introduction $^{1}$}

In the period 1954-1956, the architect, educator and planner, Max Lock (1909-1988), produced plans to modernise the historical city of Basra and to create new urban areas at Margil and the once small Gulf fishing village, turned militarily strategic port of Um Qasr in the south of Iraq (figure 1). He had worked prolifically in the United Kingdom up to and during the war time on plans for northern industrial towns until the the early 1950s when his focus became markedly more international. ${ }^{2}$ This article seeks to evaluate a portion of Lock's international work, achieving this through placing three Iraqi plans by Lock within the political and cultural context of the country. Moreover, Lock's planning methods were markedly progressive compared to his contemporaries, rendering himself as an important, yet overlooked, planner of the mid-twentiethcentury within the literature. ${ }^{3}$ Lock's scrupulous methods and social awareness made him one of the most meticulous planners of his generation using a holistic approach to creating a plan that engaged and affected the population of a place positively.

The first of the trilogy of Max Lock's southern Iraq plans began with the Director General of Ports and Navigation, Sami Fattur, appointing Lock to plan Um Qasr in 1954 (published in January 1955), sixty miles south of Basra. ${ }^{4}$ The second, also by the same client, was for the area of Margil, north of Basra. Finally, the Iraq Development Board employed Lock to produce a plan for Basra following this work and earlier successes in Britain and abroad in Jordan where Lock worked for the UN. These proposals focussed on 'local studies of human requirements for the future development of the Port town' but also featured varying degrees of interest in other more infrastructural issues, the synthesis of this formed the overall planning strategy with each report covering each theme to a different extent. ${ }^{5}$ In 1956, Basra was a date producing port-city on the Shatt al-Arab close to the Zubair oilfields in the south of Iraq, which remained under indirect British influence. Britain held interests in the region since the mid-eighteenth-century when it was part of a well-trodden path to India. Basra was a strategic point on the Arabian Peninsula for Britain, with proximity to oil fields in Abadan and Kuwait, coupled with large ports enabling access to interests further afield. March 1955 and August 1956 witnessed the finalisation of reports into the planning of Um Qasr and Margil, both utilising similar planning methods to Basra

\footnotetext{
1 MLA denotes Max Lock Archive (University of Westminster)

2 Motouch and Tiratsoo. "Max Lock, Middlesbrough," 17-20.

3 McClelland, “Inventorying Armagh: Max Lock," 1-24.

4 Lock, Report on Um Qasr, 1.

5 Lock, The Survey and Plan for Margil, 2
} 
alongside some that may appear contradictory to Lock's planning philosophy owing to personnel alterations. The 1958 Revolution which removed and killed the pro-British and Hashemite King, King Faisal II in a military led coup is one factor in the abandonment of Lock's plan. The period ensuing 1958 meant the British lost favour in Iraq through the abandonment of the Baghdad Pact, signed in 1955 which had symbolised Iraq's pro-Western, pro-British orientation of policy, quickly becoming redundant. ${ }^{6}$ The British-led Iraq Development Board, which Lock had received the commission from, became obsolete following the 1958 Revolution.

Sir Patrick Geddes - the polymath and planner - heavily influenced Lock's planning philosophies and in turn the plans in southern Iraq. Geddes had pioneered 'civic diagnosis' in the nineteenth-century, and Lock had become aware of his work during his time studying at the Architectural Association (AA). ${ }^{7}$ Like Geddes, Lock usually lived in the location he was working on, often moving his staff to the subject site and using the existing contextual surroundings to create a successful plan. Geddes' influence certainly is prominent within the focus on the fabric of the city and the urban grain, but it is the conflicting factors of modernisation and the requirement of large-scale infrastructure that is arguably at odds with this element of Lock's planning theories. This comes to a head within the Um Qasr and Margil plans, admittedly for industrial urban areas, but is contradicted within the plan for Basra which largely focuses on human aspects and sense of place.

Through addressing the trilogy of plans created by Lock for Basra, Um Qasr and Margil, this article explains his influences, previous work and the plans in southern Iraq, placing his work within the wider context of Iraq's national development. From this setting, it will become clear that importance placed on infrastructure by the clients trumped the carefully considered social and cultural issues that Lock researched so heavily through his town planning in southern Iraq, more specifically within the New Basrah Plan. Through doing this, it demonstrates Lock's varying focusses and why he may have chosen them. The first section of this article looks at Iraq's political scene, the cultural context and the employers of Max Lock to see their motives and influences on the plans and the varying degrees of focus on some of the themes. The second part of the article briefly assesses other town plans within the wider region and where Lock's work fits in with these. The final and most important section looks at Lock's plans for Um Qasr, Margil and Basra cross-referencing each other demonstrating how Lock focussed on improving infrastructure whilst also considering the human-scale and urban environment.

6 Cleveland and Bunton, A History of the Modern Middle, 310.

7 Welter, Biopolis, 116. 


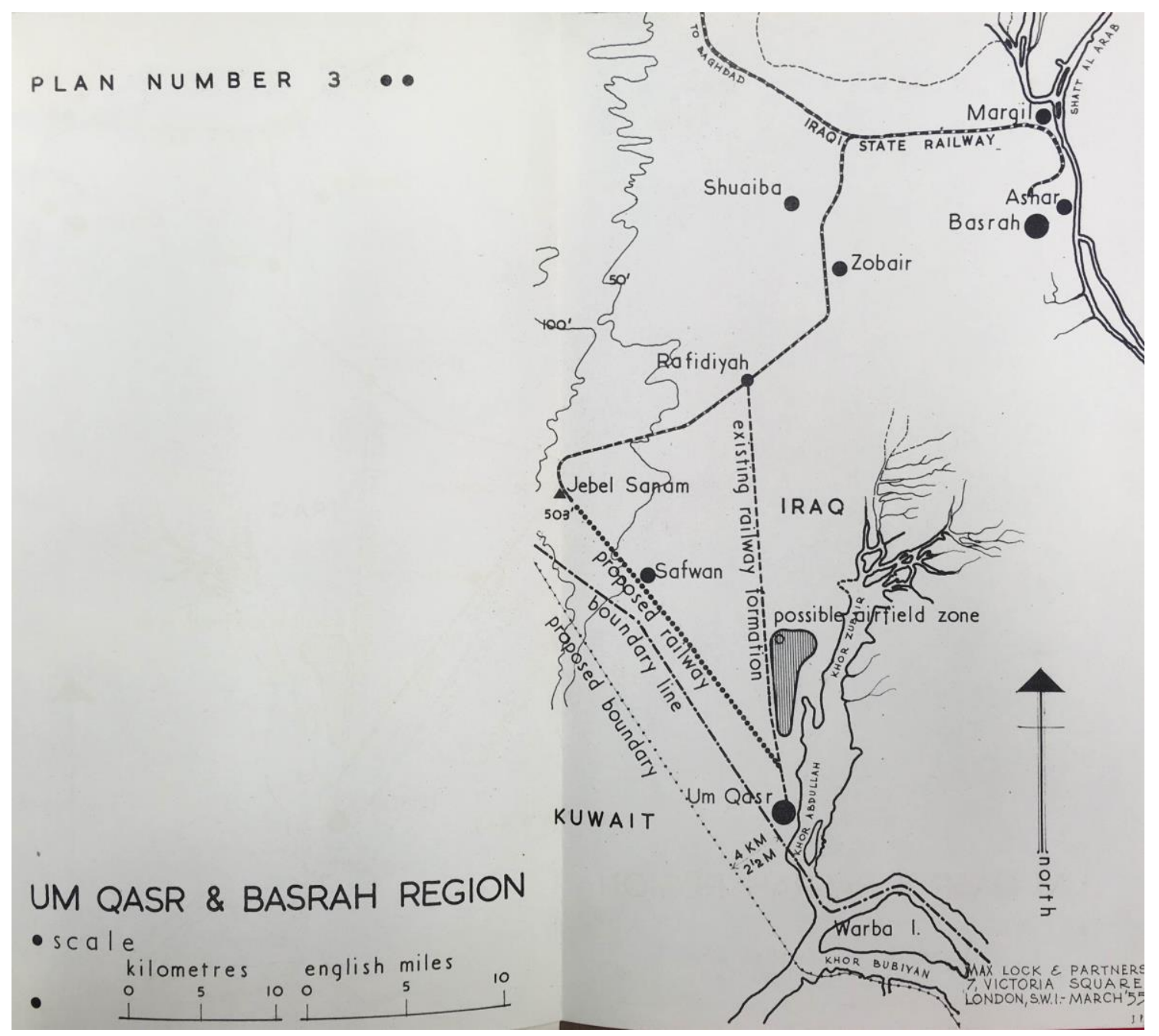

Figure 1 Map of the region close to Basra, showing the proximity of Margil to its north and Um Qasr approximately 60 miles to the south (MLA 3.26)

A Quaker, conscientious objector and 'key' member of the International Voluntary Service for Peace, Lock remained a progressive thinker throughout his lengthy career and worked with countless eminent planners and designers on various projects or in universities across the world. ${ }^{8}$ During the 1930s, he joined the Modern Architecture Research Group (MARS), with other prominent British architects, including Wells Coates and Maxwell Fry. MARS acted as an offshoot of the Congrès International d'Architecture Moderne (CIAM), expanding Lock's networks and influence within the first generation of British modernist architects. ${ }^{9}$ He completed 
'Cedar House' (1939) in Harrow in a restrained Scandinavian inspired Modernist design. ${ }^{10}$ Responding to its context through natural materials, clad mostly in timber and surrounded by birch, chestnut, beech and fir trees featuring a monopitched roof and a fenestration that spanned the length of the façade. ${ }^{11}$ Trips to Sweden reaffirmed his views that architecture was for people, an attitude that manifests itself within his town planning. In an article by Lock in the Journal of the Royal Institute of British Architects, Lock discussed how Sweden's democratic values informed architecture of the 'people for the people... serving a human and social purpose', aligning his beliefs through architecture and planning. ${ }^{12}$

In 1941 Lock was Head of School for the School of Architecture and Design at the University of Hull. During the school's evacuation from Hull he turned his thoughts to post-war reconstruction. Lock and his team of planners, sociologists and geographers produced The Hull Regional Survey: A Civic Diagnosis, which was radical in its approach and use of diagrams, visual aids and in its adoption of Geddesian philosophies. In a letter to fellow architect Ben Polk, Lock states 'every job has to be considered on its merits and there are some planners who do their planning from a taxi and others who spend months probing about 'among sites and smells which neither Brahmin nor Briton has schooled themselves to endure', quoting Sir Patrick Geddes. ${ }^{13}$ Further major commissions included plans for the Hartlepools (1946-48), a plan for Portsmouth and District (1948-49) and the Bedford Plan (1950-51), all places badly damaged in the war, where he could attempt to enact 'civic surgery.'

Furthermore, Lock's international travels were extensive throughout his career as told through his slides and photograph collection of places such as Brazil, India, Pakistan and Ceylon. ${ }^{14}$ The latter trips were lecture tours, funded by the British Council whereby he visited places touched by colonisers that had large English-speaking populations. ${ }^{15}$ In 1956 he worked as a visiting critic at the Harvard Graduate School of Design, where Josep Lluis Sert was head of school and he regularly mixed with people such as Serge Chermayeff and Lewis Mumford. ${ }^{16}$

\footnotetext{
10 Unknown, "Max Lock: Timber House in Middlesex," 510-512.

11 Ibid.

12 Lock, "The Administrative Aspect of Housing in Sweden," 917-927.

13 (Letter) Max Lock to Ben Polk, 18.01.1957, (MLA 12.2)

14 Lock's collection of slides can be found at the Max Lock Archive at the University of Westminster

15 McClelland, "Inventorying Armagh,” 3.

16 Uduku, "Networking and Strategic Deal-making," 2.
} 
Continuing from this, his employment to provide a plan and survey of the fifth largest city in oil rich Nigeria, Kaduna, in 1967 was drawn from his experiences in Middlesbrough and Hull owing to its development being a product of rapid urbanisation. The Kaduna Plan was arguably more developed than the plans for southern Iraq, with transportation viewed as a key factor. Additionally, much like with the plans for northern England in the 1940s, there was a stronger emphasis on data collection and civic surgery within the city. ${ }^{17}$

\section{Iraq and Nation Building: Context to Lock's Plan}

Lock's growing international reputation coincided with an increase of British planners and architects working abroad in tropical climates. ${ }^{18}$ Raglan Squire noted the appropriateness that British consultants worked on the modernisation of the new towns and cities in the Gulf, as England 'led the world in town planning' in this period. ${ }^{19}$ Squire's edited special feature in Architectural Design published in March 1957 covers the most important projects of the fifties by Western architects and planners working in the region. Squire had been working a plan for Mosul, also included in the feature as were Minoprio, Spencely and Macfarlane's (MSM) plans for Baghdad and Kuwait City and Lock's New Basrah Plan, published a year earlier. ${ }^{20}$ Recognising the growing number of Europeans working in tropical climes, a historiography has been expanding around this subject. Many works, such as Kenneth Frampton's Modern Architecture: A Critical History, often utilised as recommended reading for architecture students, began to look at tropical architecture, critical regionalism and phenomenological approaches to architecture particularly in the 1980s, which are all relevant to one another. ${ }^{21}$ Frampton states that a 'disturbing Eurocentric bias has been evident in almost of the received histories of modern architecture' in which he sought to rectify through the addition of architectural histories from under-studied areas of the world. ${ }^{22}$ Vandana Baweja discusses opinions such as these as being a new revisionist approach to modern architecture which challenge the Eurocentricity of the modernist historiography, ensuring that the plight of the colonised is told through 'highlighting

\footnotetext{
17 Lloyd-Jones, (lecture) Kaduna, Nigeria: Revisiting the 1967 Masterplan.

18 Polk, "Tropical Climate Control Technology," 1-4.

19 Hinchcliffe, "British Architects in the Gulf, 1950-1980," 23-36.

20 Squire, "In the Middle East," 73 - 108

21 Frampton, Modern Architecture: A Critical History, 7. Tzonis \& Lefeivre, "The Grid and the Pathway".

22 Ibid.
} 
how they were active agents in the domestication and transformation of modernist architecture and planning ideals. ${ }^{23}$ Subsequently, there was highly significant work being done in this period that until recent scholarship has escaped historical analysis due to the overbearing focus on modernism in Europe and the West.

\section{Iraq's Political Scene}

Located in the far south of Iraq, Basra is situated on the Iraq-Iran border on the Shatt al-Arab river, a key port location for access to the Gulf, and Margil is located to the immediate north of the city. Um Qasr's location is further south, closer to the Gulf and the border of Kuwait, a key strategic location in twentieth-century conflict. Basra is one of three former Ottoman vilayets, or provinces, that make up modern day Iraq, alongside Baghdad and Mosul, ${ }^{24}$ each had its own 'Vali' in Istanbul operating as separate administrations. ${ }^{25}$ Mosul, a mountainous region to the north of Baghdad, primarily relied upon Anatolia and Syria for its trade and economy. The region around Baghdad traded directly with Iran, also supported by a more agricultural economy. Basra, in the south, was 'orientated toward the Persian Gulf' and primarily traded further afield with places such as India, but ethnically and religiously, identified themselves more with the neighbouring Iranians. ${ }^{26}$ Iraq's borders were confirmed in the period following the First World War and the collapse of the Ottoman Empire, using the Sykes-Picot Agreement of 1916 as an example to divide up the Middle East between French and British spheres of influence, resulting in a lack of historical, religious and ethnic homogeneity; a confused national identity. ${ }^{27}$ For architects and planners, this scene proved a difficult context to design buildings and cities in, often tearing them between sympathetic, regionally inspired works or merely importing Western design ideologies and post-war reconstruction methods to the alien region.

Faisal II had assumed the throne in 1939, with the majority of power lying with the regent, Prince Abd al-Ilah (brother-in-law of King Ghazi (1933-39), who held this position until Faisal II 'came of age in 1953. ${ }^{28}$ Faisal II's pro-British and pre-Western stance during this period was symbolised by the signing of the Baghdad Pact - arguably the weakest of the Cold War alliances

\footnotetext{
23 Baweja, "Otto Koenigsberger and Modernist Historiography," 202-226.

24 Fieldhouse, Western Imperialism in the Middle East, (1914-1958), 69-70.

25 Ibid., 70

26 Cleveland and Bunton, A History of the Modern Middle, 195-201.

27 Fraser, Mango, McNamara, The Makers of the Modern Middle East, 63-78

28 Ibid., 310-311.
} 
- which was signed to keep British military forces within the country, as Iraq's parliament was unlikely to approve a renewal of the previous arrangements made through beliefs that the British military presence infringed on their sovereignty. ${ }^{29}$ Iraq removed itself from the Baghdad Pact following the July Revolution of 1958, led by Brigadier Abd al-Karim Qasim, when the military overthrew King Faisal II's monarchy and government prompting a decade of unstable military rule severing relations with the west and falling in to the Soviet sphere of influence. ${ }^{30}$ The postwar period saw some attempts to build and create a national identity in Iraq. The tumultuous period of politics caused the abandonment of major schemes by renowned Western architects and planners, including Frank Lloyd-wright, Walter Gropius, Alvar Aalto and Le Corbusier, these had aimed to build national identity and improve infrastructure, as had Lock's trilogy of plans in southern Iraq. ${ }^{31}$

\section{The Clients: Iraq Development Board and Ports and Navigation Authority}

Founded to aid the management of the new wealth created by oil in the country in 1950, the Iraq Development Board ${ }^{32}$ was the 'instrument' through which Iraq carried out an extensive development programme, implemented through a hastily drawn up six-year plan approved by parliament in $1951{ }^{33}$ Reasons for its failure during its existence are threefold: there was a lack of communication between the Iraqi government and the board, there was an absence of political stability to back the plan fully and thirdly there was not the technical expertise required in the official circles to approve their plans fully. ${ }^{34}$ In the Board's plan, it stipulated the need for education and public health programmes, which it was believed, would create 'more efficient human beings who would make greater contributions to the economic and political development of the nation. ${ }^{35}$ Several British officials sat on the board, including Mr. M. G. Ionides, the former secretary of the British National Council of Building Material Producers and Director of

29 Ruane, "Seato, Medo and the Baghdad Pact : Anthony Eden, British Foreign Policy, 169-200.

30 Cleveland and Bunton, A History of the Modern Middle, 311

31 Akcan, "Global Conflict and Global Glitter: Architecture of West Asia," 317-345.

32 Haberman, The Iraq Development board: Administration and Program, 179-187.

33 Those who have written on the Iraq Development Board attribute the main interests of the board to be of agricultural and irrigation issues

34 Romero, The Iraqi Revolution of 1958, 10.

35 Salter, The Iraq Development Board: A Plan of Action, 35. 
Development in Jordan, where Max Lock had been working prior to working in southern Iraq. ${ }^{36}$ It was documented that in the creation of irrigation systems, the Board generally opted for American and British consultants while French and German contractors regularly won work because of attractive low bidding, but rarely contracts were kept inside Iraq. ${ }^{37}$ The Board undertook an ambitious programme linking major cities of Iraq with surfaced roads building a 'complementary system of secondary feeder roads', mostly focussing upon the building of infrastructure. ${ }^{38}$ The part of the programme that accelerated most quickly was the construction of public buildings, schools, clinics, hospitals, and low-cost housing, which also included the planning of major towns and cities such as Basra, Mosul and Baghdad. Also included in the programme was the construction of a new royal palace, a parliament building and a museum, including contracts awarded to Le Corbusier, Frank Lloyd-Wright and Alvar Aalto. Following the chaos of the July Revolution in 1958, the Iraq Development Board ceased to exist and with it many of its incomplete projects. ${ }^{39}$ However, places such as Um Qasr were built in the communist period that followed not involving Lock in the process.

\section{Town Planning in the Region}

As each nation in the Gulf began to reap the benefits from trading oil in commercial quantities and build their own countries, major cities and towns required modernisation. Gradually, architects and planners began to build new identities through the built environment for these cities, this was not without some lacklustre attempts. As many commentators have noted, modernisation and nation building often contradicted the ultra-conservative ruling families' ideologies, particularly in the cases of Iraq, Iran, Kuwait and Saudi Arabia. ${ }^{40}$ Funded by oil, and appointed by King Faisal II in conjunction with the Iraq Development Board in 1954, MSM produced a plan for Baghdad preceding a plan produced by the Greek planner Constantinos Doxiadis a year later. ${ }^{41}$

\footnotetext{
36 Ionides, M. G. (1961) Paper delivered to a joint meeting of the Society and the Chadwick Trust, 'Human Progress and Economic Growth in the

Developing Countries'.

37 Haberman, Economic Review, 179-187.

38 Ibid, 185.

39 Kingston, Britain and the Politics of Modernisation in the Middle East, 104.

40 Fieldhouse, Western Imperialism, $69-80$

41 Lock's own annotated version of the: Minoprio, Spencely and Macfarlane: The Master Plan for Baghdad (1954) (MLA 1.3)
} 
The employment of MSM to overhaul the old town of Kuwait in 1951 occurred immediately prior to Lock working in Basra. ${ }^{42}$ Their plan included the eradication of the old city, including the walls that defined its boundary, and provides a suitable contrast to the type of planning produced by British firms to that of Max Lock's. MSM had worked on large-scale new town plans in Britain, their most well-known being Crawley, completed in 1950, giving them experience was planning ex nihlo. 'A difficult commission', Anthony Minoprio admitted, the Kuwaiti's wanted a new city, but all MSM could give Kuwait City was 'what we knew', importing the same theories as had upheld the British post-war 'new town', as they believed them to be the most advanced ideas in global town planning. ${ }^{43}$ The plan for Kuwait placed great importance on zoning areas, with the central business district in the historic core with suburban housing units and zones on the periphery showing MSM as acting as 'agents of Empire'. Before the plan's production, open spaces, parks, sports grounds and playing field were non-existent in Kuwait, with provision of these stressed in their final plan. ${ }^{44}$ The degree of focus on the creation of open spaces can be compared to the importance Lock placed on parks and leisure areas within Um Qasr, Margil and Basra. ${ }^{45}$ While these were MSM's recommendations, it was also the wish of the Kuwaiti ruler Abdullah al-Salem al-Sabah (1950-1962) that the new city was functional, well-planned with good communication networks with wide roads, in order to make Kuwait a 'modern' metropolis. ${ }^{46}$ Critics of the plan, including Alissa Reem and Farah al-Nakib prominent names in the recent literature to proliferate around Kuwait's modernisation, have argued the plan encouraged decentralisation and sprawl, focussing on the needs of the automobile. ${ }^{47}$ Countering Lock's approach of 'civic surgery' and focussing on planning in line with British policy produced in the Town and Country Planning Act (1947) and the New Towns Act (1946), MSM recommended a homogenised style of city that displaced people away from its centre, disregarding the existing Arab urban grain that had developed in the centuries prior to its development. ${ }^{48}$

\footnotetext{
42 Gardiner, Kuwait: The Making of a City, 33.

43 Al-Nakib, “ Kuwait’s Modern Spectacle, 1950-1980,” 7-25.

44 Albaqshi, The Social Production of Space, 8-85.

45 Lock, The Survey and Plan for Margil, 53-58.

46 Al-Nakib, Kuwait's Modern Spectacle, 10.

47 Reem, "Modernising Kuwait: Nation-building and Unplanned Spatial Practices”, 85-90.

48 Al-Ragam, "The Destruction of Modernist Heritage: The Myth of Al-Sawaber," 243-252.
} 
Raglan Squire's plan for Mosul conformed with Lock's ideology more than the plan produced by MSM for Kuwait, highlighted within the special edition of Architectural Digest in 1957. ${ }^{49}$ Iraq's split from three distinct Ottoman territories was prevalent in Mosul and shown through its infrastructure and links to the rest of modern Iraq. To the east of Mosul is Nineveh, the former capital of the Assyrian Empire located on an ancient route from Europe to central Asia. Necessary improvement to communications and infrastructure with the new capital of Iraq, Baghdad to Mosul's south, was to be a major focus of the plan. ${ }^{50}$ Where Lock had used urban fabric that existed in his earlier plans in Middlesbrough and Hull, the post-war reconstruction needs in Britain favoured the clearance of whole sites. Unlike MSM in Kuwait, Squire recommended that there should be minimal 'mutilation' of property. ${ }^{51}$ To do this, it was necessary to remove whole buildings or blocks of buildings to provide access to the high-quality bits of Mosul's heritage, as a form of his own civic surgery. In Squire's words the plan would 'enable a rational road system to be evolved, aerate the closely packed districts, permit roads and squares but enough for car parking, and established conditions of amenity comparable with those in newer parts of the town, thereby arresting any serious exodus from the area and preventing the creation of a slum. ${ }^{52}$

\section{Max Lock's Trilogy of Plans in Southern Iraq: Um Qasr, Margil and Basra}

\section{The Condition of Basra}

Commercial oil production began at the Zubair oilfield near Basra in 1951, leading to the necessity for a town plan and the commission from the Iraq Development Board to Max Lock in 1954. The growing export of oil from the region also prompted a new port area at Um Qasr and Margil to be planned by Lock in reports published in 1955 and 1956, focussing on infrastructure but also the human requirements and scale essential to ensure a genius loci. ${ }^{53}$ The Iraq Development Board required the plan owing to the fragility of the government and scepticism

\footnotetext{
49 Squire, "In the Middle East," 73 - 108.

50 Ibid., p. 74

51 Ibid.,73-108.

52 Ibid., 73-108

53 Haberman, “The Iraq Development board: Administration and Program,” 179-187. Lock, The Survey and Plan for Margil, 2. \& Lock, Report on Um Qasr, 1
} 
shown towards the Board following a lack of progress. ${ }^{54}$ The Board wanted a focus on housing which would 'reach out to the wider public' giving them the visible signs of progress needed to secure the unstable government and new-monarchy's futures. ${ }^{55}$ Basra's piecemeal development and wartime destruction left it in a poor condition upon Lock's arrival. At the end of the First World War, engineer George Buchanan remarked that he had 'never before in all of my life seen such a hopeless mess and muddle' regarding the condition of Basra. ${ }^{56}$

Basra's location leant itself favourably to encouraging a diverse demographic of people, with many migrating from the rural regions of southern Iraq looking for industrial employment. The 1947 census of Iraq recorded Basra's population as being 101,000, which Lock and his associates estimated had grown to 143,000 by 1955 attributing its growth to migrants from Amarah and Nasiriyah, where there had been problems of land tenure due to the silting up of land 'forcing living standards down even below subsistence level. ${ }^{57}$ The new city was based to the north of the port area, where British Petroleum had constructed shops in 1938 which was ringed by simply built sarifa dwellings (figure 2), housing regional migrants employed by the burgeoning trade and oil sectors. ${ }^{58}$ On initial reflection, Lock described Basra as being a 'scattered and fragmented community' which was 'physically and socially sub-divided into three widely separated townships, with Basrah as the head, Ashar the body and the port of Margil an important and active arm', reflected in his attention to detail within his report for Margil, too. ${ }^{59}$ In order to keep up with migration, development was usually hasty and ad hoc, resulting in poorly connected neighbourhoods and sub-standard construction.

\footnotetext{
54 Ibid.

55 Pyla, “Rebuilding Iraq, 1955-58: Modernist Housing, National Aspirations, and Global Ambitions," p. 71.

56 Jackson, "The Architecture of the British Mandate", 382.

57 Ibid., 20.

58 Khoury, “Making and Unmaking Spaces of Security: Basra as Battlefront, Basra Insurgent, 1980-1,” 130. \& Lock, The Survey and Plan for Margil, 1-73. 


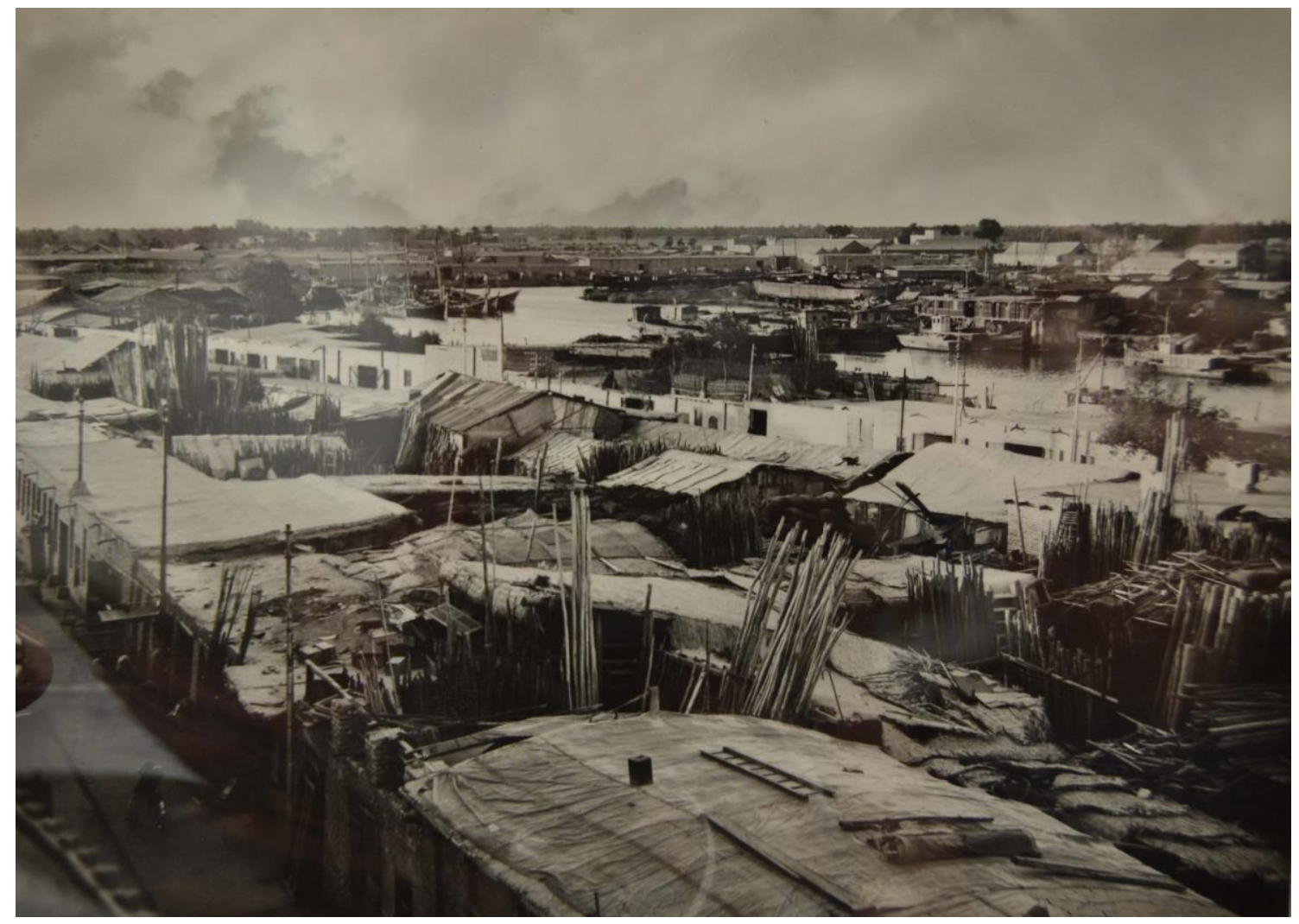

Figure 2 Low-rise 'sarifa' dwellings characterise Basra located on waterways (MLA 6.12)

Lock believed surveying the town thoroughly before implementing a plan was imperative, demonstrated specifically in previous works at Middlesbrough and Hull, while this is evident in Basra, there is not as much focus on surveying in Margil or Um Qasr because until at least the 1920s, Margil was a swamp featuring some date trees and Um Qasr was a small fishing village until it was utilised in the Second World War as a temporary port to get goods from the West to the Soviet Union. ${ }^{60}$ With regards to urban areas and interventions, Lock wrote 'before derelict and blighted areas can be removed, new communities grafted on, traffic congestion eased, a thorough 'medical examination' or penetrating 'civic diagnosis' is needed' which was completed through a 'systematic' series of surveys of existing conditions, 'which counts as much as the plan itself - for it is the starting point from which all plans are made. ${ }^{61} \mathrm{He}$ asserts in the report's introduction that Town Planning is the science of 'civic surgery', a derivation of Patrick Geddes' 'conservative surgery' which means 'amending and improving an urban quarter by minimising the destruction of existing buildings, let alone the demolition of whole areas, for the 
sake of new houses and structure. ${ }^{\prime 62}$ The New Basrah Plan was a thorough report and survey of the condition of Basra prior to the 1958 Revolution in Iraq, providing a snapshot of its condition in this unique period. Lock's reports on Margil and Um Qasr focussed more on the creation of new towns and areas for habitation rather than concentrating on a survey of the conditions, possibly due to the 'new' nature of the housing. ${ }^{63}$ Lock explains in his report on Margil' existing housing, that many dwellings were built for workers between 1930 and 1935 and these reflect their occupants' social status or position within a company. ${ }^{64}$

Lock agreed that Basra required work to make it function like a large port town should, but he also saw intrinsic qualities in its urban grain and architecture stating that there are few towns in Iraq that have a more 'inherent charm' and that its improvement would come at a 'moderate cost' due to its character being a town of 'waterways, quiet streets and narrow lanes flanked by brick buildings in the Turkish style' (figure 3) ${ }^{65}$

In these narrow lanes, first-floor bay-windows framed in timber project and almost meet, each carrying richly ornamented fascias and overhanging eaves, the windows themselves being protected from the sun by decorative jalousies. These add dignity, colour and shade to quiet residential quarters, and call to mind the street pattern of Venice, with its waterside walks and narrow lanes creating an atmosphere of dignity and quiet intimacy. ${ }^{66}$

Basra had aesthetic qualities but it was clear to Lock that the city's function did not meet the demands of a modern metropolis. While his plan sought to enhance waterways, and conserve the historic fabric of the city, he also suggested the creation of several new roads linking the three predominant areas that had developed in recent times. However, aims of the Iraq Development Board did not align with Lock's work showing that he did not research wider transport links adequately contrasting to his thorough work on the condition of Basra, possibly because he had done with Margil and Um Qasr. ${ }^{67}$ Contrary to this, there does appear to be an awareness of the national situation, which the Board wanted Lock to focus on. Lock understood the parameters

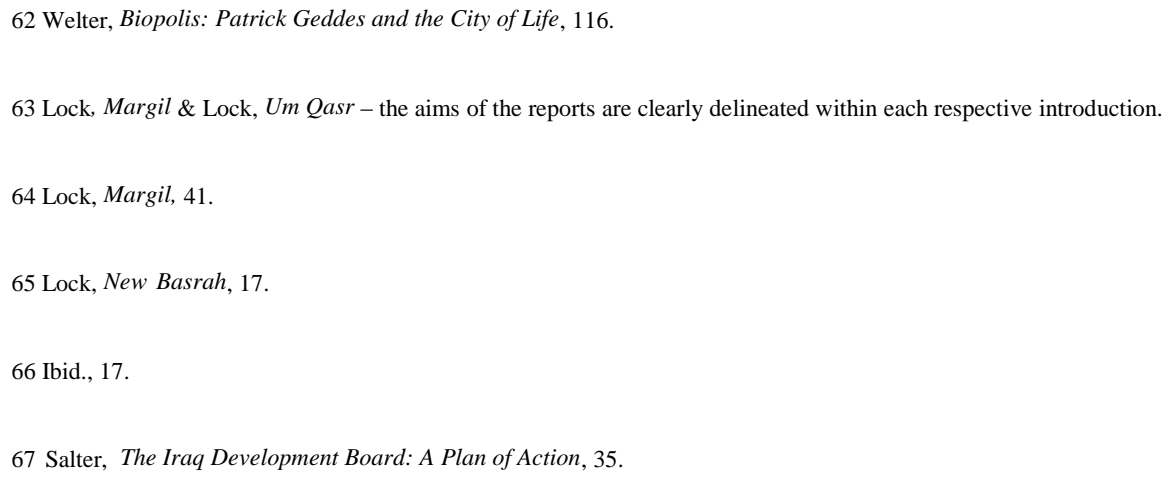


dictated by the regional nature of Iraq and analysed how his plans for Margil and the port of Um Qasr worked within the wider remit of the country. He does this through explaining that the port at Basra is 'synonymous' with the development of Iraq as a whole. ${ }^{68}$ The 'railhead' being the terminus of the country' main transport artery, as well as the Wilson Mason designed airport being one of the 'best equipped' in the Middle East, which he explains is a 'major junction in world airline communication. ${ }^{69}$

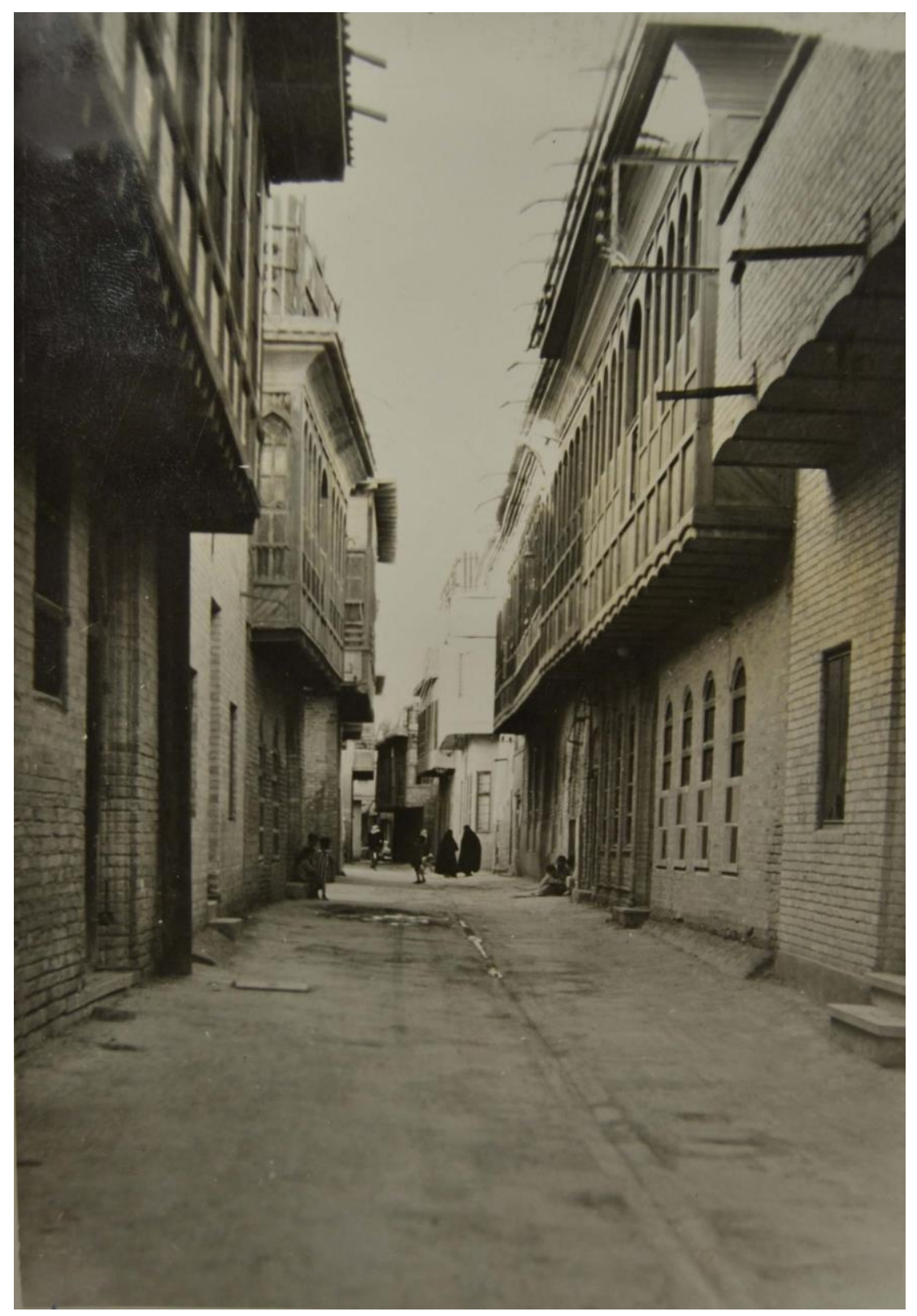

Figure 3 'Narrow streets flanked by buildings in the Turkish style' (MLA 6.12)

68 Lock, Margil, 4

69 Ibid. \& Jackson, “Architecture of the British Mandate Iraq", 45. 
The 'Condition of Properties Map' (figure 4) displayed the condition of historic fabric with information attributed to it through a colour coded system in four separate categories:

1. Buildings of long life (over twenty years)

2. Buildings of limited life (5-20 years)

3. Buildings for immediate redevelopment

4. Sarifa development (dwellings of mud and palm matting $)^{70}$

This map, in conjunction with the Land Use survey (figure 4), also produced in the report, intended to show where the city's 'black spots and blighted areas' were located with a suitable programme of rehabilitation commencing after these findings. For Basra, this was imperative, but there was no such detailed visual research into Margil or Um Qasr more a notion of rebuilding what was there or just completely starting from nothing. However, similar to Basra, Lock is aware of who he is designing neighbourhoods for through his description of new housing at Shatt-AlTurk, an area of Margil, when he states his objective here: 'The Consultants' objective in planning this community is to design one that is economical to build, that is sociologically integrated, that respects the tradition of living established among Iraqi families, and aims at minimizing extremes of climate', while it was a newly built and planned area of a town, Lock shows complete awareness through his surveying of the region of who he is designing for and the ways in which people live. ${ }^{71}$ In a separate report on the creation of Um Qasr, the relevance of creating a town from nothing is raised but Lock's methods through 'personal interviews' with a 'large number of persons' and the 'bodies whose livelihood and existence are tied up with the port of Basrah' yielded the results from which he would make the proposals for Um Qasr, rather than looking at the, albeit minimal, existing fabric remaining from its fishing village and military days. ${ }^{72}$

70 Lock, New Basrah, 13

71 Lock, Ubullah Neighbourhood, Margil, 11.

72 Lock, Um Qasr, 5. 


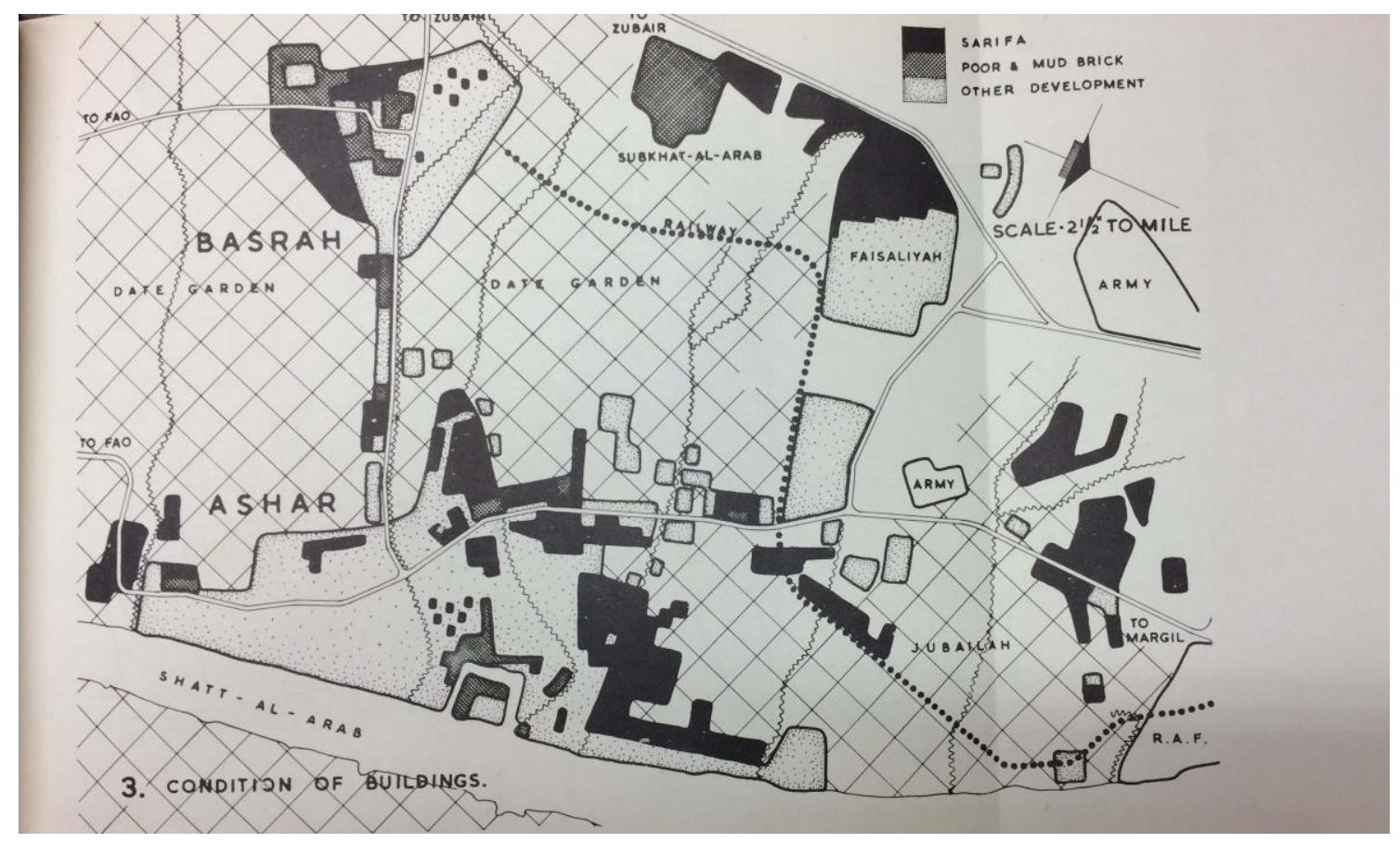

Figure 4 Conditions of properties map (Max Lock, The New Basrah Plan, MLA 6.12)

The importance of civic surgery is the topic of a letter to the Editor of the Manchester Guardian, whom Lock was chasing up for the retrieval of a copy of the Basra report. In the letter, he writes:

We have, in replanning the city of Basrah, endeavoured to follow some of the principles laid down by Sir Patrick Geddes in his work in India. Although a great deal of the housing must be swept away wholesale; some of the neighbourhoods in the brick built parts of the town centre, erected mostly under the Turkish regime, can be retained and improved by the process described by Sir Patrick Geddes as 'civic surgery', in which bad buildings are cleared away to give more light and air to those which exist, and an appropriate degree of 'infilling' is inserted to retain the urban character of these attractive, well shaded streets. ${ }^{73}$

Residencies in Basra was an issue for Lock having stated 'Housing problems in the city are immense and the need to tackle them urgent. ${ }^{, 74}$ Lock's detailed analysis on Basra showed that fifty-nine percent of the total population lived in 'sarifa' dwellings or poorly constructed mud brick houses, which he attempted to alter in his plan through building new neighbourhoods thus dispersing the population outwards with strict control with regards to standards of construction, 
maintenance and hygiene (figure 3). ${ }^{75}$ In comparison, Margil, estimated that $60 \%$ of the population in Margil were unskilled workers or artisans who either lived in mud brick or 'reed dwellings' which were susceptible to being 'washed away' by heavy rains. ${ }^{76}$ The materials used for new dwellings did not have to differ, as mud brick and reeds had been used for centuries in a bid to combat the often harsh climatic conditions. ${ }^{77}$ The dispersal of the population into new massbuilt dwellings is reflective of mid-twentieth-century European planning trends. Projects such as Le Corbusier's Unite de Habitacion and Sheffield City Council's Park Hill developments were contemporary Western case studies in the eradication of slums and poor health in cities. In Europe, new projects required the clearing of large swathes of land, with many of the New Town planners in Britain supporting schemes of clearance in London championed by the 1947 Town and Country Planning Act. In Basra, Lock suggests a more restrained approach by the wholesale demolition only of areas that the surveys reveal an 'economic value of nil. ${ }^{78}$ Lock did not want to alter the character of the city, so by attempting to improve traffic circulation around the main Bazaar streets, there could be a 'gentler, less drastic, treatment' to the urban fabric, opposing the wholesale demolition of the entire city dissimilar to the lack of surveying of material and the existing landscape at Margil and Um Qasr. ${ }^{79}$

In an aim to reduce infant mortality rates - which he used to measure the standards of healthcare - Lock suggested zoning new residencies on the periphery of the city. He likened Basra's infant mortality rates with Middlesbrough, a deprived area of northern England. 250 of every 1000 births resulted in death in Basra, compared to 34 per 1000 in developed regions and countries, improving this, would suggest the newly implemented plan for healthcare was a success. ${ }^{80}$ Lock believed that better education in schools and housing improvements would aid Basra's health and social problems, and thus, the city's overall condition. The biggest killers in Basra in 1954 were traceable to polluted water or congested living conditions. ${ }^{81}$ By changing this through the establishment of better sewage disposal, dry refuse collections and the dispersal of

\footnotetext{
75 Ibid., 41-44.

76 Lock, Margil, 42.

77 Ibid.

78 Lock, New Basrah, 17.

79 Ibid.

80 Ibid., 42.

81 Ibid.
} 
housing away from areas likely to be more polluted, outbreaks of malaria, bilharzia, trachoma, hookworm and tuberculosis could be minimised. ${ }^{82}$ With regards to Margil, Lock is overly negative about the healthcare situation despite remarks about national improvement suggesting that 'considerable progress in public health has been made in recent decades. ${ }^{83}$ Lock's advice for improvement of healthcare at Margil is urgent, saying that the current facilities 'are quite inadequate for a town of 28,000 population. ${ }^{, 84}$

\section{Civic Areas}

Across all three plans for Um Qasr, Margil and Basra, Lock placed great prominence upon the creation of a genius loci within civic spaces and areas. Despite the close chronological proximity in production to one another, each plan focussed upon this very differently. Arguably, the New Basrah Plan was more conservation led, through the acceptance that Basra's historical fabric was of vital importance in the creation of place. However, where Lock made drastic interventions, particularly in places such as Margil, there appears to be little consideration for the traditional networks of streets that identify the towns situated in this region and he attempted to plant Western style grid patterns, specifically in Um Qasr, instead of constructing something more synonymous with the usual urban grain found in this region (figures 5 and 6) ${ }^{85}$ Despite this, there is a clear Arab language within the architecture that Lock imagines around the town centre in Margil including traditional courtyard houses and a minaret at the centre of a large public plaza. ${ }^{86}$ Architecture and Arab design is particularly focussed upon within the report into the creation of the Ubullah Neighbourhood in Margil. ${ }^{87}$ Again, the centre of the development is similar to Margil's with landscaped large open spaces and a tall minaret at the centre, but the architecture is lacking any serious Arab identity. This is rectified within his designs for several house types within the area with all elevations lacking any façade details, all built with a courtyard and around a central communal area. Lock appears to understand the micro-planning nature of housing and dwelling within these communities, but his understanding of the city and its civic areas is majorly lacking possibly owing to the lack of a recognisable European styled 'centre' within towns and

\footnotetext{
82 Ibid., 63.

83 Lock, Margil, 50.

84 Ibid., p. 50.

85 Ibid., Bird's Eye View of Town Centre. Margil.

86 Ibid.

87 Lock, Ubullah Neighbourhood, Margil, 10.
} 
cities within the region as the centre was usually defined by the souk within a tight network of streets located within a city wall. ${ }^{88}$

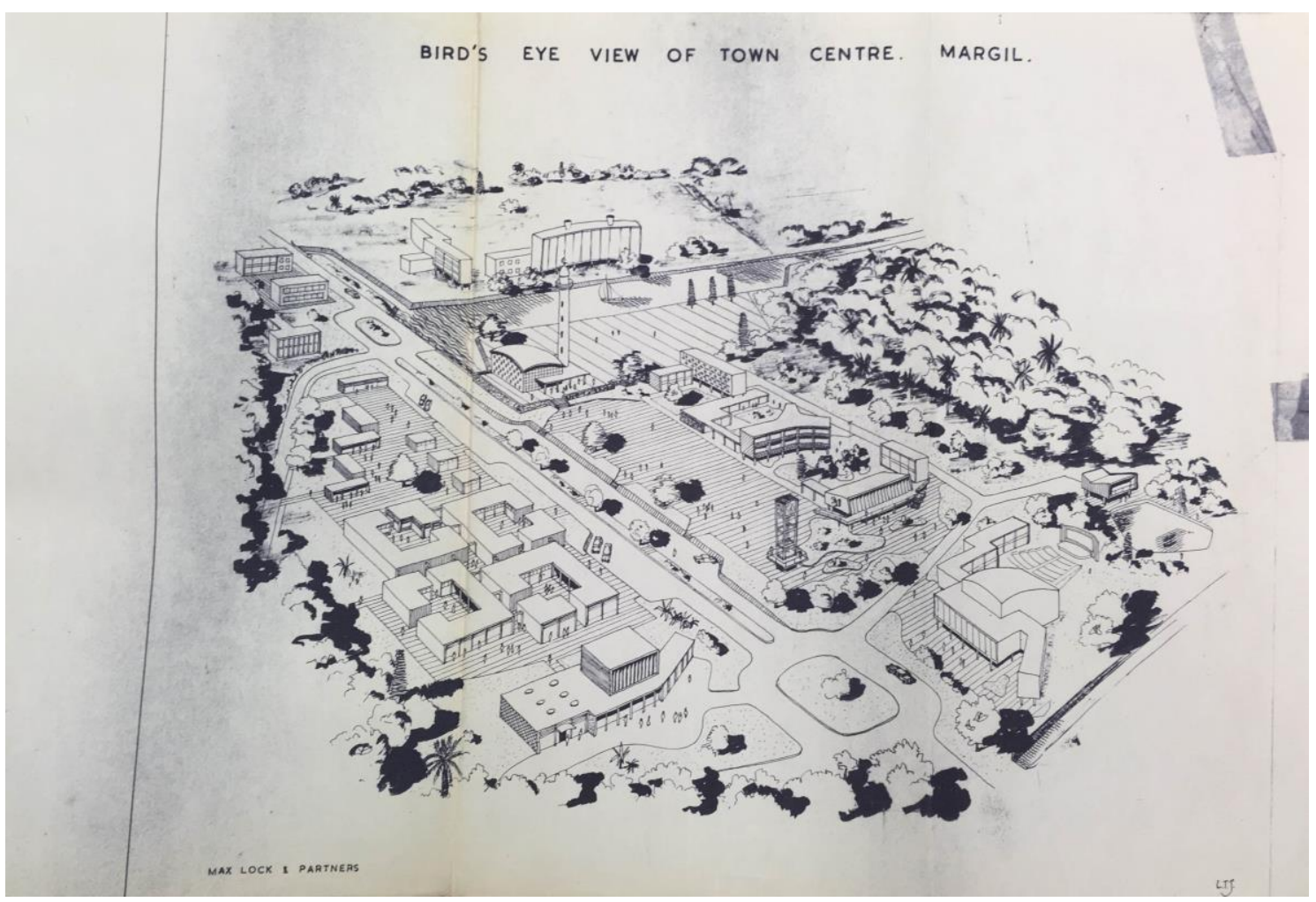

Figure 5 Margil Town Centre, taken from Max Lock's report on Margil (1956) 


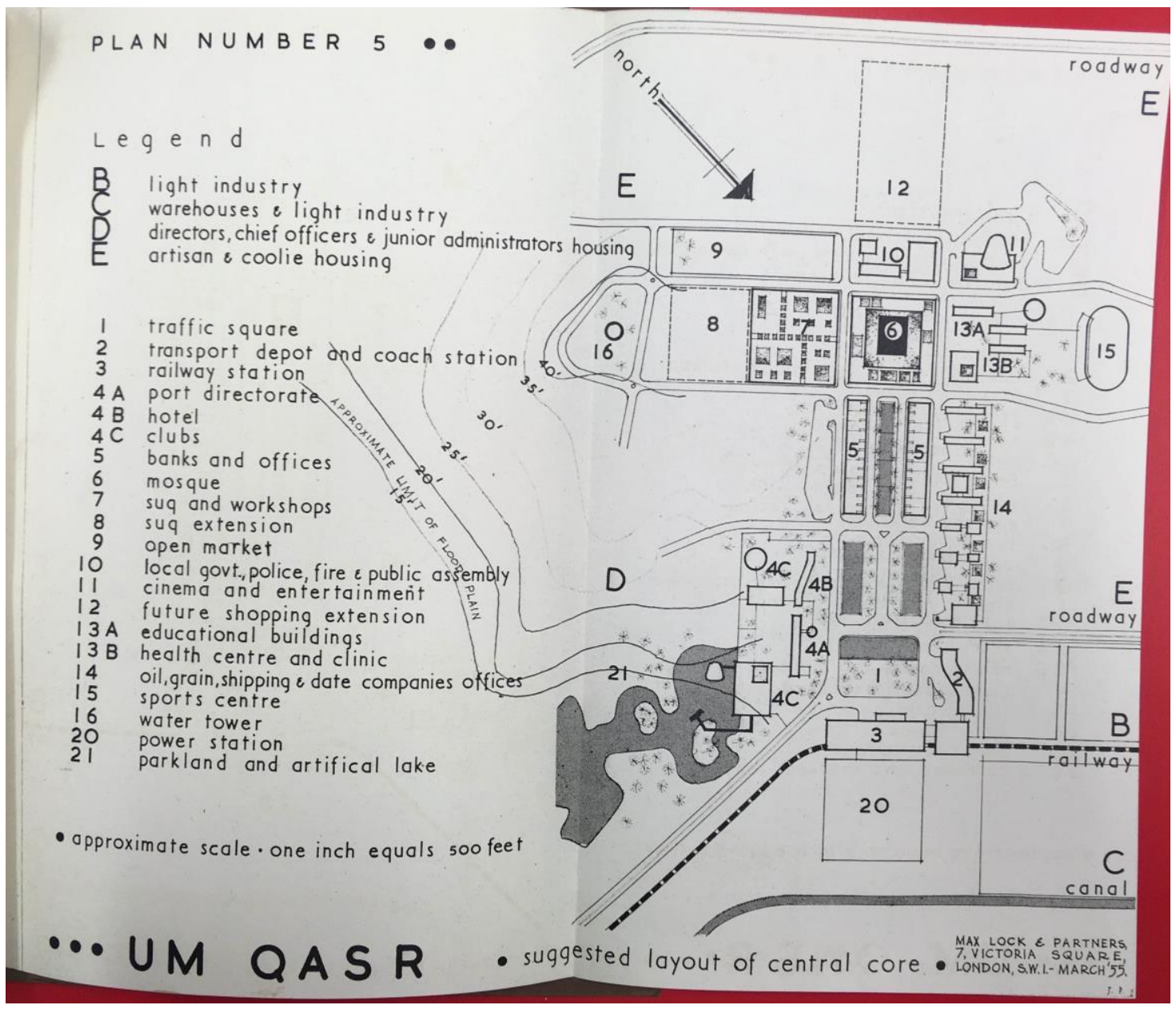

Figure 6 This plan shows Lock's proposals for Um Qasr win which he wanted to plant a town on a geometric grid based on axes and zoning, typical to the new Western cities rather than designing it similar to the ad hoc urban grain formed over the centuries previous around the Gulf which enabled constant breezes and permanently shaded areas

\section{Basra's Transport Solution}

Key to the failure of the New Basrah Plan was Lock's lack of focus on macro-infrastructure. Geography of the area dictates transport and its solutions around Basra. Lock endeavoured to link older parts of Basra with the new, industrial areas on its periphery, focussing on cars, boats and trains in his report. In contrast, because of the nature of the creation of ports and port towns at Margil and Um Qasr these reports largely focussed on the 'macro' elements of transport often looking either to wider Iraq, the Persian Gulf and the world as well as focussing on the micro elements linking the areas of Basra to the new ports efficiently. ${ }^{89}$ Lock even placed some emphasis on the 'abnormally large number of cyclists' who often had a 'marked lack of road sense' which 
he sought to remedy through ensuring they cycled around roundabouts the correct way. ${ }^{90}$ Affordable personal transport fuelled urban growth, in which Basra was no different to European cities, but its roads were not suitable for a modernising, industrialising city. ${ }^{91}$ Lock noted that a 'careful survey' had been made so that traffic circulation may be improved without 'destroying the inherent charm' of the areas, placing civic surgery at the centre of this proposed intervention. ${ }^{92}$ Lock asserted that one of the most urgent problems in the city was owing to the growing volume of traffic primarily caused by increasing numbers of "large private cars. ${ }^{193}$ This was to be relieved with provision for more parking in important areas, such as Souqs, to enable people to drive to get their shopping or meet socially or for business. ${ }^{94}$ Iain Jackson asserts that the transport infrastructure required to modernise Iraq - and in this case Basra - seems 'banal', but was paramount to make state institution buildings, such as the palaces and universities, valid when nation building. ${ }^{95}$ In Margil, in particular, the focus on infrastructure through the middle of civic areas is shown on diagrams placing an importance on the car and getting to a central location in one forcing streets to become wider for cars to fit and thus demonstrating a lack of sympathy for traditional urban fabric of the Arab city, but perhaps this is because he is primarily focussed on how people live rather than 'authentic' Arab and Gulf city design. ${ }^{96}$

\section{Roads}

Lock's transport plans for cars can be read on two scales - large and small - with large pieces of road infrastructure, including intersections of seven major roads merging - built to serve wider districts connecting the city together as well as linking to major roads north to Baghdad. ${ }^{97}$ The smaller scale roads would link the new, zoned, residential areas to the places people needed to be, such as the market place or mosque. ${ }^{98}$ In the New Basrah Plan Lock included plans for national

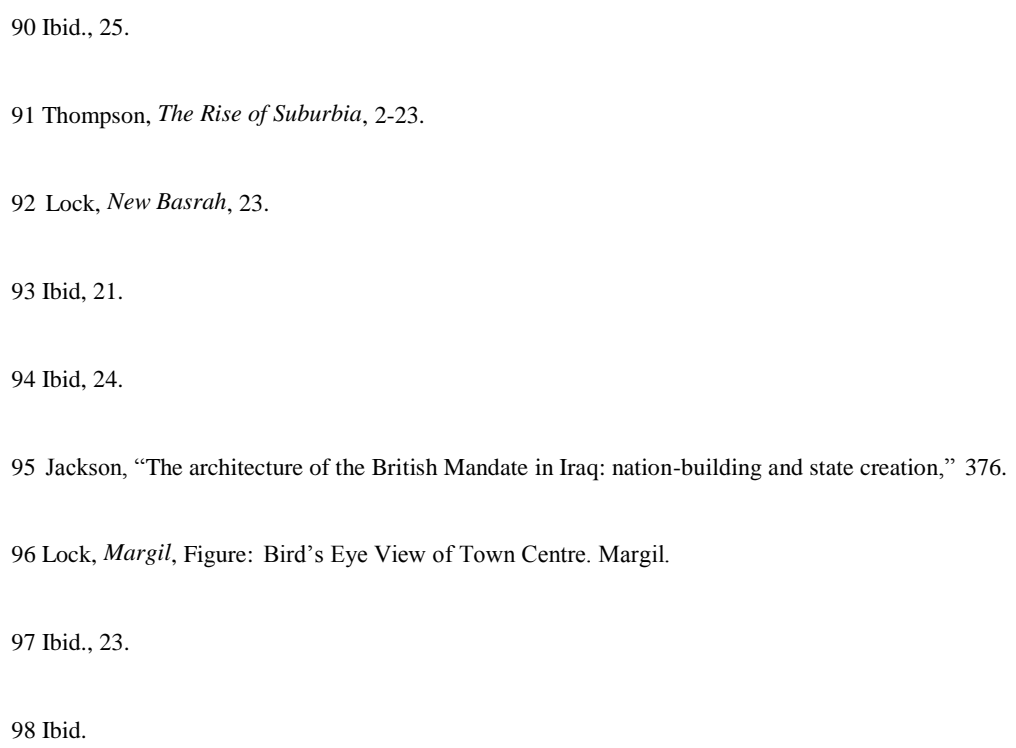


infrastructure, but in comparison to his nuanced research and plan for the city's fabric the focus on linking Basra to the other regions of Iraq was minimal. Furthermore, in the earlier plan for Margil, Lock is openly critical about the Development Board's lack of focus for new roads to the south of Basra to link Um Qasr to the north of Iraq. He states: 'The importance of a first-class highway from Basrah and Um qasr to Baghdad and Mosul cannot be over-emphasized, and if the project for a new port were to go forward the roads programme of the Development Board, which does not envisage any extension of the existing system south of Basrah, would have to be revised. ${ }^{99}$

\section{Trains}

Hierarchically, the New Basrah report placed train infrastructure below car and road travel. Lock recommended to remove the single-track train connection between Margil and Basra as it would become obsolete because of proposed road improvements. ${ }^{100}$ Railways were still of importance with a goods and passenger line between Basra and Baghdad the subject of debate at least five years before Lock published his report with Basra acting as the terminus in the south for Iraq's rail services. ${ }^{101}$ Due to Basra's location at the confluence of the three major rivers at the foot of the Gulf pilgrim traffic from India, Pakistan and Iran was high and it was intended that these pilgrims would embark direct from Ashar on to trains to Karbala near Baghdad and Najaf in the south-central region of Iraq. ${ }^{102}$ Lines existed in varying forms dating from the First World War and built from second hand materials from India with the aim to give the British army easier access north. ${ }^{103}$ Lock also saw the benefits in local train travel, propositioning an extension of the railway of Margil to Ashar and as far as Rabat Creek to serve workers on date and grain sites alleviating traffic congestion in the city. ${ }^{104} \mathrm{He}$ also sought to remedy this with the 're-allignment' of national train services through Margil, in light of the removal of the single-track connection. ${ }^{105}$ Intended improvements to trains were not intended to be drastic, but they would solve some

\footnotetext{
99 Lock, Margil, 11.

100 Ibid., 26.

101 Al-Khattab, Basra City: A Study in Urban Geography, 71.

102 Lock, New Basrah, 26.

103 Al-Khattab, Basra City: A Study in Urban Geography, 71.

104 Lock, New Basrah, 26.

105 Lock, Margil, 30
} 
congestion problems, reduce road building and the effect on the existing urban grain resulting in the need for less civic surgery.

\section{Waterways}

Waterways throughout Basra are both a key characteristic of the townscape, but also imperative for transporting goods and people, Lock also describes the waterway network in Iraq as 'great potential for commercial navigation' which remained unexplored in the plans for Margil and Um Qasr. ${ }^{106}$ Conserving the waterways, yet making them efficiently usable, was imperative to the notions of 'civic diagnosis' that Lock employed through his Basra plan and survey (figure 7). Shallow waters in the Shatt al-Arab had inhibited river trade, forcing Basra to become a main port and transhipment point between seagoing and flat-bottomed river boats. ${ }^{107}$ In a national context, Lock had proposed to improve 'all-the-year-round' navigation on the Tigris, resulting from the reason that the river was the most cost-effective method of transporting bulk cargoes between Baghdad and Basra, causing an increase in river traffic - this is what Lock had intended to plan for. ${ }^{108}$ Lock had surveyed the area around Ashar noticing that during the harvest season for dates and grain this induced 'chaotic conditions' in the waterways prompting a suggestion that these should be 'widened, dredged and locked in position' (figure 7). ${ }^{109}$ Waterways, their dredging and general use was much of the focus of the later Coode and Partners report into Um Qasr, which incorporated Lock's previous research into this area of Basra. The report looks in detail at the port area and much of the science of tides as well as existing structures around the river, particularly wharves. ${ }^{110}$ Lock's diagnosis for waterways was to improve their efficiency through their physical improvement and the building of wharves owing to the 'unsightly' open storage areas that were formed, but also recognising that elements of the waterways formed a key element of the character of Basra and its townscape.

\footnotetext{
106 Ibid., 26.

107 Al-Khattab, Basra City: A Study in Urban Geography., 34.

108 Lock, New Basrah, 27.

109 Ibid., 27.
}

110 Coode and Partners, Investigation into Port Development at Um Qasr, 1-83. 

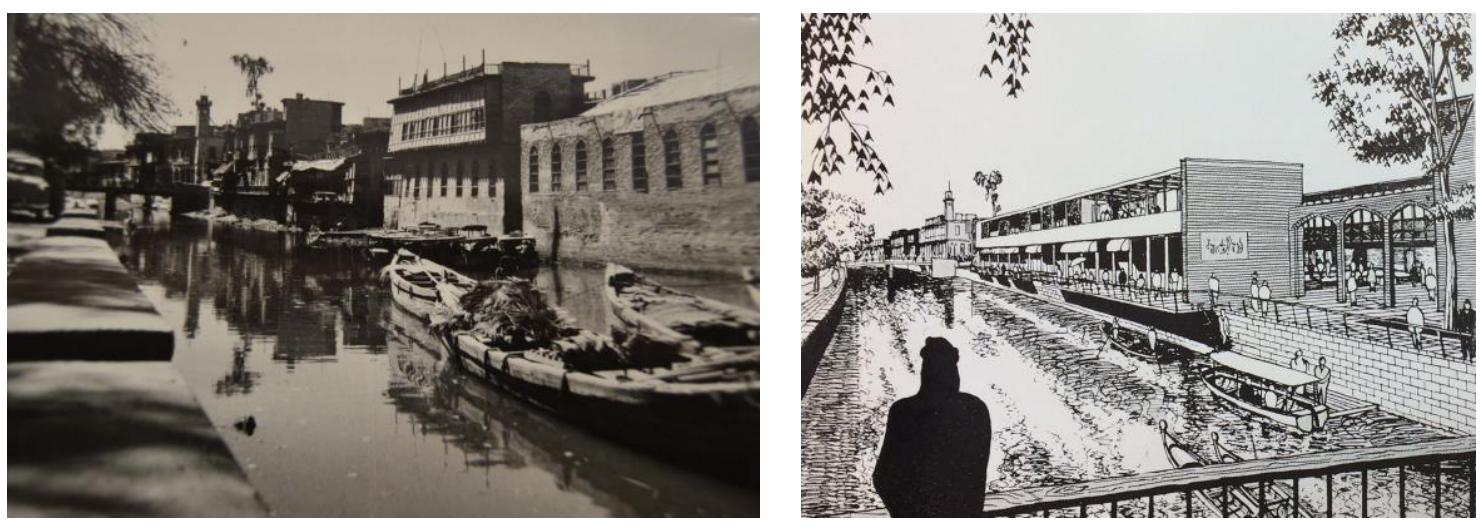

Figure 7 A current and proposed development alongside the characteristic waterways of Basra, preserving the most notable features from the Ottoman period (Max Lock, The New Basrah Plan, MLA 6.12)

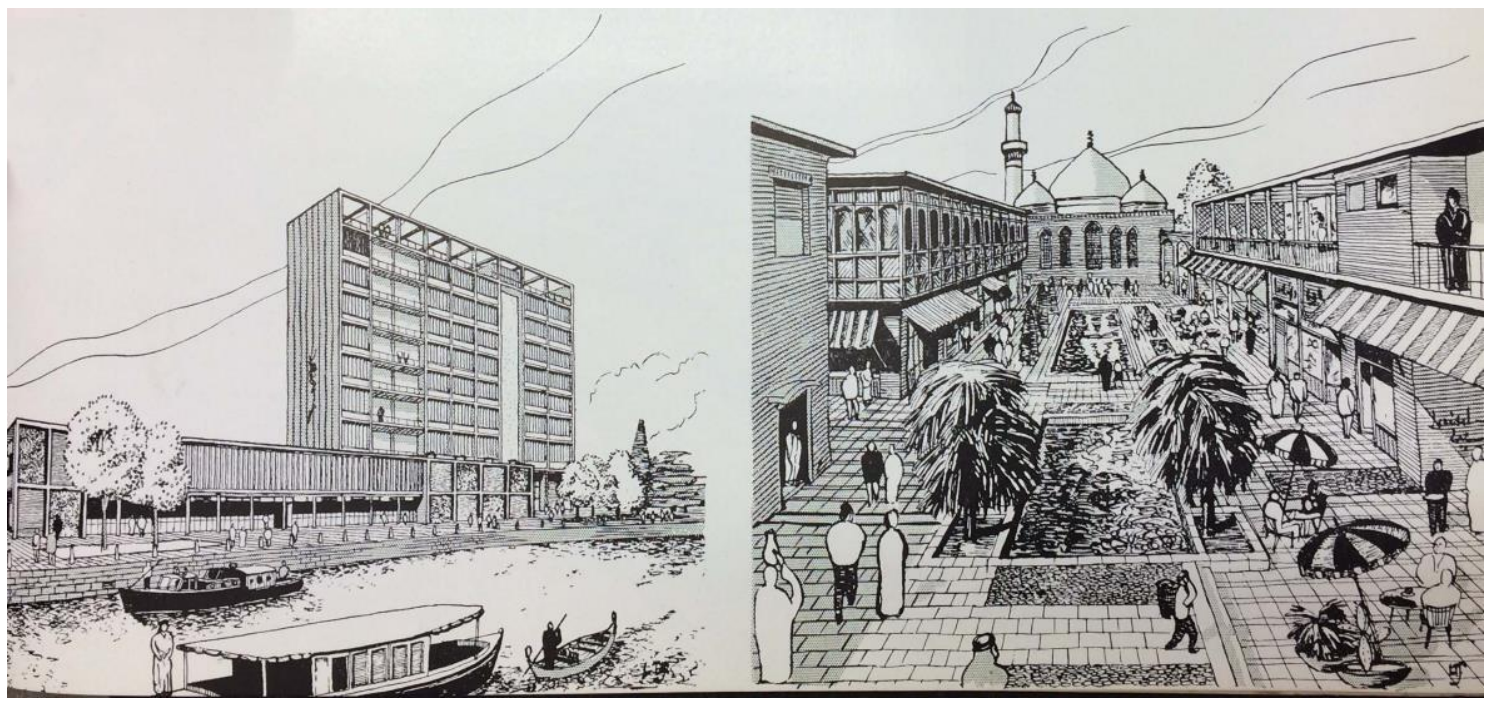

Figure 8 The importance of restoring Ottoman style buildings in prominent public places and the production of civic space shown through these proposed images of Basra (Max Lock, The New Basrah Plan, MLA 6.12)

\section{Education}

Education received a degree of emphasis in planning reports for Iraq prior to the 1958 Iraq Revolution, despite it being an inherent issue within the state. Historically consumed within a wider 'civilising' rhetoric of imperialism, the Iraqi government desired to modernise its people through the creation of education facilities noted through the prominence of school building during the 1950s. At this time, education was not compulsory so the provision for schools, especially in places such as Um Qasr was paramount for the children of the new population but 
also their parents in the government' push to combat illiteracy. ${ }^{111}$ Throughout the Gulf during the fifties the construction of many schools designed by Western architects became commonplace due to the growing need to educate the population as Arab countries became 'awoken'. ${ }^{112}$ Lock noted in his report that the attitudes of people required change to facilitate the cultural alterations needed to ensure success. One of these cultural changes that would be difficult to overcome was that it was 'still prevalent for children, rather than their fathers, to be the family wage earners.' 113 Consequently, only one fifth of the seventy percent of children that attended full time primary school continued full-time to the intermediate and secondary schools within the city. ${ }^{114}$ In other areas of the country, the employment of architects to construct new school buildings was commonplace. However, resulting from the detailed survey Lock carried out prior to the creation of a plan, Lock suggested that there was no need to build primary schools from scratch, as the existing fabric in many buildings would suffice, emphasising Geddesian philosophies of civic surgery. ${ }^{115}$ Throughout this period of 'nation building', this focus on educational building was important and this is also reflected through Lock' reports for southern Iraq. Specifically, Lock's belief was that education was a basic consideration for 'agricultural, industrial and technological progress in Iraq as well as for the fuller development of the country's cultural life. ${ }^{116}$ Placed within the wider political and social context, Lock's awareness and reasoning behind educational planning plays an undeniable role within the overall ideology of nation and identity creation.

\section{The Plan's Realisation and Rejection}

Uncertainty surrounded Lock and the implementation of his plans. In 1951, The Iraq Development Board had published its Six Year Plan for major works of capital reconstruction finishing a year early. ${ }^{117}$ Lock stated that it had a fund of 500 million dinars, there was sufficient doubt as to how much Basra would see of this pot. ${ }^{118}$ According to a review of the development plan in 1955 by Lord Salter, the exact timings became undefined referring to a desire to not be

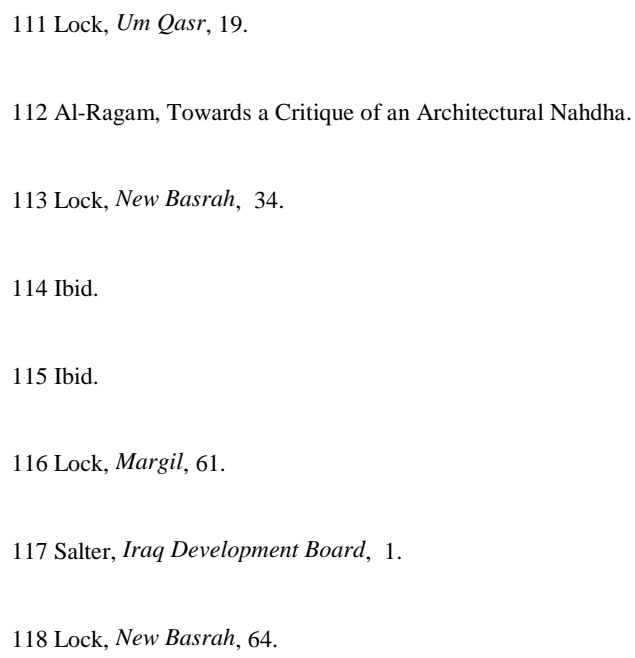


like the failed totalitarian states' plans of five years that had taken place in decades gone by. ${ }^{119}$ This plan was enacted in late 1955, superseding the first six-year-plan. ${ }^{120}$ In 1956 Lock's New Basrah Plan became a publication on a small print-run with its distribution to several renowned figures in planning across the globe with the plans for Margil and Um Qasr only reaching those in office due to them remaining unpublished. ${ }^{121}$ The plan for Margil was unrealised, but incorporated into a further plan by British firm Coode and Partners with that not being used and the plan for Um Qasr was also unrealised but formed part of the wider research for later plans after the revolution when Iraq was in the sphere of Russian influence.

Following The New Basrah Plan's publication, the Development Board promptly shelved the plan of which there are several reasons for. In the mid-1950s, the creation, acceptance and cancellation of plans by the Iraq Development Board and government was commonplace. The New Basrah Plan's shelving occurred in one of these reshuffling of national plans. The differences between them often lied within what the focus of the plan was to be. Lock's plan, being liberal and socially aware, fell foul to the desires of many of these plans which were usually macro-infrastructure-centric and looked to stitch Iraq together as a nation rather through communication channels such as roads and trains, as his proposals at Um Qasr and Margil had focussed upon. These opposed Lock's ideas where he focussed on micro-scales through his version of Geddes' civic surgery, shown by his attention to the fabric of the city in the New Basrah Plan. Due to the tumultuous nature of Iraq's political system, propped up by external nations and the failing British Empire, the 1958 July Revolution caused the cessation of most projects submitted under the various guises of the Iraq Development Board during the 1950s - including the plans for Margil, Um Qasr and the New Basrah Plan produced by Max Lock confining them to history.

\section{Conclusion}

The trilogy of plans produced by Max Lock in southern Iraq in the 1950s vary in their ideologies and focal points but provide an interesting snapshot of a new country looking to build an identity whilst modernising on a rapid scale, economically, socially and culturally. The New Basrah Plan draws on influences from greats such as Patrick Geddes, and contemporaries such as Lewis Mumford, Lock's plan focussed on the minutiae that created the sense of place required to make a city a place, rather than concentrating on how to link Basra to the rest of Iraq, which was to be

119 Salter, Iraq Development Board, 9.

120 Qubain, The Reconstruction of Iraq 1950-57, 43.

121 Letters from the Max Lock Archive at the University of Westminster show the interest among his contemporaries in the New Basrah Plan. 
a contributing factor to its shelving by the Iraq Development Board. However, in his plans for Margil and Um Qasr, Lock focussed upon wider infrastructure opposing his focus on 'place making' within Basra in the New Basrah Plan. Where Lock looked to expand Basra to other cities and nations, he looked extrovertly to the region of the Persian Gulf, internationally - mostly to Europe as that is where the majority of trade came from - and to other areas of Iraq. Lock did this through a concentration on the port and the riverine links to the Gulf as well as suggestions of road building in the plans for Um Qasr and Margil, retaining Basra's road, sea and air links to Iraq, the Gulf and the globe.

It is clear from the plans for Um Qasr and Margil that they would have satisfied the Iraq Development Board's desires for linking Basra to the wider world for trade and infrastructure in Iraq, allowing Lock to focus on creating a sense of place in Basra utilising the local architecture and historical links to its Ottoman past. Lock's planning processes were far more time consuming but conducive to creating a better living environment with an emphasis on the creation of place, which is what he focussed on in Basra. However, within the three plans there are great differences. For example, the Basra plan focusses largely on the existing conditions and conducting civic surgery on the urban fabric, while plans for Margil, which was 'swampy shoreland' until the First World War rather than the historically developed centre that Basra was. ${ }^{122}$ Lock' wider theories are prevalent in his provision for education, he accepts that the system is slightly behind the West (i.e. no co-educational system) but looks to provide enough space for children and adults in the combat against illiteracy within Iraq, the placement and number of schools was determined through the extensive social and economic research Lock and his teams provided at the beginning of each report.

In the context of the time, Lock's surveying of urban and built fabric, where possible, coupled with Geddesian philosophies was almost unique in the Persian Gulf, barring Raglan Squire's plan for Mosul which did this to an extent. MSM demolished the historical fabric of Kuwait, seemingly at the orders of the Kuwaiti government. They were entirely happy to order this and work a new, modern city into its location with very little opposition from the Kuwaiti populace. Lock's proposals for Basra attempted to usher in an era of modernisation through its urban form by using the fabric that already existed within the cityscape but also providing new urban areas at Margil and Um Qasr which allowed for the growth of trade links between Basra, Iraq, the Gulf and the rest of the world. The Iraq Development Board believed that Lock had not focussed upon implementing the levels of infrastructure required to modernise to the extent that they desired, despite the clear efforts within the plans for Margil and Um Qasr commissioned by 
the Basra Port Directorate and Lock's contradictory criticism of the Board not focussing enough attention on road building south of Basra. Thus, the New Basrah Plan focussed on things the Iraq Development Board were not ready to consider despite the consideration for macro-planning which was evident within the plans for Margil and Um Qasr shown through the analysis of transport within the town areas and its wider influence in the Persian Gulf, Iraq and the rest of the world. Lock's trilogy of plans demonstrates both his desire to plan and aid people through the creation of place with a genius loci as well as creating cities to play a role in the modernisation of Iraq and the wider region through an emphasis on infrastructure.

\section{Acknowledgements}

I would like to thank those who have helped with the production of this article at the Max Lock Archives, University of Westminster. I am grateful for the advice from my former tutors at the University of East Anglia, Dr Sarah Spooner and Dr Jon Gregory as well as my PhD supervisor at the University of Kent, Dr David Haney. I am eternally grateful for the support from my parents and family throughout this process. 


\section{Bibliography}

Abu-Dayyeh, N. I. "Persisting vision: plans for a modern Arab capital, Amman, 1955-2002." Planning Perspectives 19, no. 1 (2006): 79-110.

Akcan, E. (2014) Global Conflict and Global Glitter: Architecture of West Asia (1960-2010) in A Critical History of Contemporary Architecture. (eds.) Haddad, E. G. \& Rifkind, D. (Ashgate: London) pp. 317-345.

Albaqshi, M. A. The Social Production of Space. PhD Diss., University of Illinois, 2010.

Al-Khattab, A. A. Basra City: A Study in Urban Geography, PhD Diss., SOAS, 1972.

Al-Nakib, F. "Kuwait's Modern Spectacle, 1950-1980" Comparative Studies of South Asia, Africa and the Middle East 33, no.1 (2013): 7-25.

Al-Nakib, F. Kuwait Transformed: A History of Oil and Urban Life. Stanford: Stanford University Press, 2016.

Al-Ragam, A. "The Destruction of Modernist Heritage: The Myth of Al-Sawaber." Journal of Architectural Education 67 no. 2 (2013): 243-252.

Al-Ragam, A. Towards a Critique of an Architectural Nahdha: A Kuwaiti Example (PhD Diss. University of Pennsylvania, 2008)

Baweja, V. "Otto Koenigsberger and Modernist Histroiography." Fabrications 26 no.2 (2016): 202-226.

Bununu, Y. A. Ludin, A. N. M. and Hosni, N. "City Profile: Kaduna." Cities 49 no.1 (2015): 5365.

Cleveland, W. L. \& Bunton, M. A History of the Modern Middle East. Philadelphia: Westview, 2016.

Crinson, M. "Abadan: planning and architecture under the Anglo-Iranian Oil Company." Planning Perspectives 12 no.1, (1997): 341-359.

Coode and Partners. Investigation into Port Development at Um Qasr. (1955) (Unpublished: MLA 3.25)

Fieldhouse, D. K. Western Imperialism in the Middle East, (1914-1958) Oxford: Oxford University Press: Oxford, 2006.

Frampton, K. Modern Architecture: A Critical History. Fourth Edition. London: Thames and Hudson, 2007.

Fraser, T. G. Mango, A. McNamara, R. (2011) The Makers of the Modern Middle East. London: Haus, 2011. 
Gardiner, S. Kuwait: The Making of a City. Harlow: Longman, 1983.

Haberman, S. J. “The Iraq Development board: Administration and Program.” Economic Review 9 no.1 (1955): 179-187.

Hinchcliffe, T. 'British Architects in the Gulf, 1950-1980', M. Fraser and N. Golzari (eds.), Architecture and Globalisation in the Persian Gulf Region, London: Ashgate, (2013): 23-36.

Ionides, M. G. "Paper delivered to a joint meeting of the Society and the Chadwick Trust." Human Progress and Economic Growth in the Developing Countries. 1961.

Jackson, I. "The architecture of the British Mandate in Iraq: nation-building and state creation." The Journal of Architecture 21 no.3 (2016): 375-417.

Khoury, D. R. Making and Unmaking Spaces of Security: Basra as Battlefront, Basra Insurgent, 1980-1, in Violence and the City in the Modern Middle East, (ed.) Fuccaro, N. Stanford: Stanford University Press, 2016.

Kingston, P. W. T. Britain and the Politics of Modernisation in the Middle East. (Cambridge: Cambridge University Press, 1996.

Lloyd-Jones, T, (2010) Kaduna, Nigeria: Revisiting the 1967 Master Plan, Lecture, Urban Design Group

Lock, M. The New Basrah Plan. London: Max Lock and Partners, 1956.

Lock, M. “Across Lapland.” The Architectural Association Journal, (1938): 424 - 431.

Lock, M. "The Administrative Aspect of Housing in Sweden." The Journal of the Royal Institute of British Architects. 47 no.8 (1939): 917-927.

Lock, M \& Partners. The Survey and Plan for Margil, (1956). (Unpublished: MLA 3.24.)

Lock, M \& Partners. Report on Um Qasr, (1955). (Unpublished: MLA 3.26)

McClelland, A. G. "Inventorying Armagh: Max Lock, civil society, and the diffusion of planning ideas into Northern Ireland in the 1960s." Planning Perspectives. 32 no.3 (2017): 1-24.

Motouch, N. \& Tiratsoo, N. "Max Lock, Middlesbrough, and a forgotten tradition in British postwar planning." Planning History 26 no.2 (2004): 17-20.

Odum. H, W. "Patrick Geddes' Heritage to the Making of the Future." Social Forces 22 no. 3 (1944): 275-281.

J. E. Peterson. Britain and the Gulf: At the periphery of Empire in L. G. Potter (ed.) The Persian Gulf in History. London: Palgrave, 2009.

Polk, B. "Tropical Climate Control Techniques", Architectural Record 25 no. 4, (1964): 1-4. 
Pyla, P. "Rebuilding Iraq, 1955-58: Modernist Housing, National Aspirations, and Global Ambitions." DOCOMOMO, 35 no.3 (2006): 71-77.

Qubain, F. I, The Reconstruction of Iraq 1950-57. New York: Praeger, 1958.

Reem, A. I. R. Building for Oil: Corporate Colonialism, Nationalism and Urban Modernity in Ahmadi, 1946-1992. PhD Thesis: University of California, Berkeley, 2012.

Reem, A. 'Modernising Kuwait: Nation-building and Unplanned Spatial Practices', Berkeley Planning Journal, 22 no.1, (2012): 85-90.

Romero, J. The Iraqi Revolution of 1958: A Revolutionary Quest for Unity and Security. Lanham, MD: University Press of America, 2000.

Ruane, K. "Seato, Medo and the Baghdad Pact : Anthony Eden, British Foreign Policy and the collective defence of south-east Asia and the Middle East, 1952-1955." Diplomacy and Statecraft 16 no.1 (2005): 169-200.

Salter, A. The Iraq Development Board: A Plan of Action. London: Caxton Press, 1955.

Squire, R. (Ed.) “In the Middle East.” Architectural Digest, (1957): 73 - 108.

Thompson, F. M. L. The Rise of Suburbia. Leicester: St Martin's Press, 1982.

Tzonis, A \& Lefeivre, L. "The Grid and the Pathway: An introduction to the work oof Dimitris and Suzana Antonakakis", Architecture in Greece, 15 (1981): 164-178.

Uduku, O. Networking and Strategic Deal-making in the Caribbean: Using Archives to Examine Max Lock's 1950s planning adventures in the West Indies, ABE Journal. 4 (2013):

Unknown, "Max Lock: Timber House in Middlesex." Journal of the Royal Institute of British Architects 47 no.3 :2013): 510-512.

Unknown, “Scalby Reception Centre, Yorkshire.” Architects'Journal, (1940): pp. 172-175.

Welter, V. M. Biopolis: Patrick Geddes and the City of Life. Cambridge, MA: MIT Press, 2002.

\section{Archive Material}

(Lecture), November 1957, 'Design in Music and Architecture', and letters in the archive show he was a senior and founding member of the International Voluntary Service for Peace (MLA 10.3)

(Letter) Max Lock to Ben Polk, 18.01.1957, (MLA 12.2)

(Letter) Unknown to unknown, 12.11.1957 (MLA 10.3)

(Letter) Serge Chermayeff to Max Lock (November 1957) (MLA 10.3)

(Letter) Max Lock to the Editor of the Manchester Guardian, 05.02.1957 (MLA 12.2) 
